\title{
Palynological Studies of Some Species of Aspleniaceae-Pteridophyta
}

\author{
Gamal M. A. Lashin
}

Department of Botany, Faculty of Sciences, Zagazig University, Zagazig, Egypt.

Email: gamalsabaa@yahoo.com

Received November $23^{\text {rd }}, 2011$; revised December $17^{\text {th }}, 2011$; accepted January $4^{\text {th }}, 2012$

\begin{abstract}
Palynology of six fern species belonging to the family Aspleniaceae from Saudi Arabia are investigated by light microscope (LM). These are: Asplenium aethiopicum, Asplenium trichomanes, Asplenium adiantum-nigrum, Asplenium sp.1, Asplenium sp.2 and Ceterach officinarum. All studied spores are oblate-spheroidal in shape class, with $11-50 \mu \mathrm{m}$ in equatorial diameter and with $12-49 \mu \mathrm{m}$ in polar diameter. Two types of spores are recognized: monolete spores in Asplenium aethiopicum, Asplenium trichomanes, Asplenium adiantum-nigrum, Asplenium sp.2 and trilete spores in Asplenium sp.1 and Ceterach officinarum. The exospore (perine) is homogeneous and apparently double-layered in all the studied spores. The perispore is single or double-layered with a microlacunouse structure. The perispore layers can be distinguished by their different contrast, structure and thickness. The exospore sculpture varies from cristates-ridged (Asplenium aethiopicum), cristates granulate (Asplenium adiantum-nigrum), cristates scabrate (Asplenium trichomanes), regulate-scabrates (Asplenium sp.1 and Ceterach officinarum) to papillate or tuberculate sculpture (Asplenium sp.2). Comparison between the earlier studies of some species from Saudi Arabia is given. General characteristics like spore type, ornamentation and laesurae features as well as the number of exospore layers could be useful for taxonomy of Aspleniaceae.
\end{abstract}

Keywords: Aspleniaceae; Ferns; Palynology; Pteridophyta; Saudi Arabia

\section{Introduction}

The Aspleniaceae (spleenworts) is a family of ferns, included in the order Polypodiales or in some classifications as the only family in the order Aspleniales. All Members of this family have intramarginal, linear sori with a flap-like indusium arising along one edge [1]. Most pteridologists today consider this family as consisting of just one to three genera. Others still maintain segregate genera such as Phyllitis and Ceterach; however, the species segregated into these genera all hybridize readily with undisputed Asplenium species. A phylogenenetic study of Aspleniaceae, shows that species segregated as Camptosorus and Neottopteris are nested within Asplenium [2]. It also recommends that they be included in that genus, but suggests that Hymenasplenium (including Boniniella) and Phyllitis are distantly related to other Asplenium species and should be recognized at the generic level. The type species for the genus is Asplenium marinum. Some botanists treat Aspleniaceae as comprising a single genus, Asplenium, but up to nine small segregate genera are recognized by other botanists $[2,3]$. Many groups of species have been separated from Asplenium as segregate genera. These include Ceterach,
Phyllitis, and Tarachia, but these species can form hybrids with other Asplenium species and because of this are usually included in a more broadly defined Asplenium $[4,5]$. The newer classifications place it in the subordinal group called eupolypods within the order Polypodiales. Asplenium is one of the largest fern genera, of about 700 species, distributed worldwide from Greenland and Europe to South America and New Zealand [6]. It occurs in a wide variety of exposed or partly shaded habitats, e.g., on rocks, in low-altitude semi-deciduous woodland, wet evergreen forest and (sub) Montana rain forest. Various segregates have been proposed (e.g. Camptosorus, Phyllitis, Ceterach, Pleurosorus), but numerous "intergeneric" hybrids occur. The most unusual allopolyploid phytogeographically is Asplenium adiantum-nigrum, the parents of which are known only in the Old World [7]. Polyploidy is widespread in Asplenium and the chromosome numbers vary from $2 \times$ to $6 \times$. Two species, Asplenium trichomanes and A. heterochroum, occur in different levels of polyploidy $-2 \times$ and $4 \times$, and $4 \times$ and $6 \times$, respectively. The highest chromosome number known for Asplenium in North America is $2 \mathrm{n}=216$ (in $A$. trichomanes-dentatum and the hexaploid form of $A$. 
heterochroum) [2,3]. Mickel [8] mentioned that the spore characteristics were useful to differentiate some genera and he compared to other spore-bearing vascular plants. Spores of Asplenium are monolete; perispore typically winged, spiny, reticulate, or perforate.

This contribution is part of the study of Pteridophyta spores that grow in South West Saudi Arabia. The work aims to provide palynological data, as a complement to the general knowledge of the species $[9,10]$. The aim of this study is to investigate the spore morphology and wall ultrastructure of six species of family Aspleniaceae growing in the South West Saudi Arabia by using LM. The results will be used for the general morphology, and the ultrastructure studies to see if the spore characteristics could be used successfully for systematic purposes.

\section{Materials and Methods}

Spores were obtained from herbarium specimens of biological department, Faculty of Sciences, King Khaled University, Table 1. The plant specimens were identified according to [11-13]. Spores of the different specimens were studied by using light microscope (LM). For LM the spores were treated with $3 \%$ hot sodium carbonate for 2 min and acetolyzed according to $[14,15]$. All the observations were performed with Olympus BH2 and BHB light microscopes. Slides housed at the biological department, Faculty of Sciences, King Khaled University.

\section{Results}

The Fern spores examined are monolete type (four species) and trilete types (two species). Spore colour is brown, yellow, or black-brown. Various types of spore surface are found including cristate, folded, granulate, papillates and scabrates or some combination of these features. The spores produced by the selected species are spheroidalshape, $11-50 \mu \mathrm{m}$ in equatorial diameter and $12-49 \mu \mathrm{m}$ in polar diameter, the exospore is $0.5-3 \mu \mathrm{m}$ thick, smooth and the perispore is $0.3-1 \mu \mathrm{m}$ thick and ornamented (Tables $\mathbf{2}$ and 3, Figures 1 and 2).

\section{Spore Descriptions}

1) Asplenium aethiopicum (Burm. P.) Bech.

Acrostichum filar Forssk.

Asplenium filar Forssk.

Asplenium lanceolatum Forssk.

Spores are monolete, pheroidal, sometimes large and compressed, with an irregularly cristate perine (exospore) and winged folds sometime with few ridges. Spores are light-brown or yellowish in colour. The spores averaged and varied in size from $32.5-35 \mu \mathrm{m}$ in polar diameter and $35-37.5-40 \mu \mathrm{m}$ in equatorial diameter (Figure 1(a), $\times 1000$ and see Table 2). The sori and the underside of the frond are covered with reddish scales on the young fronds and $1-3 \mathrm{~cm}$ length.

Table 1. The sites of collection of the studied species.

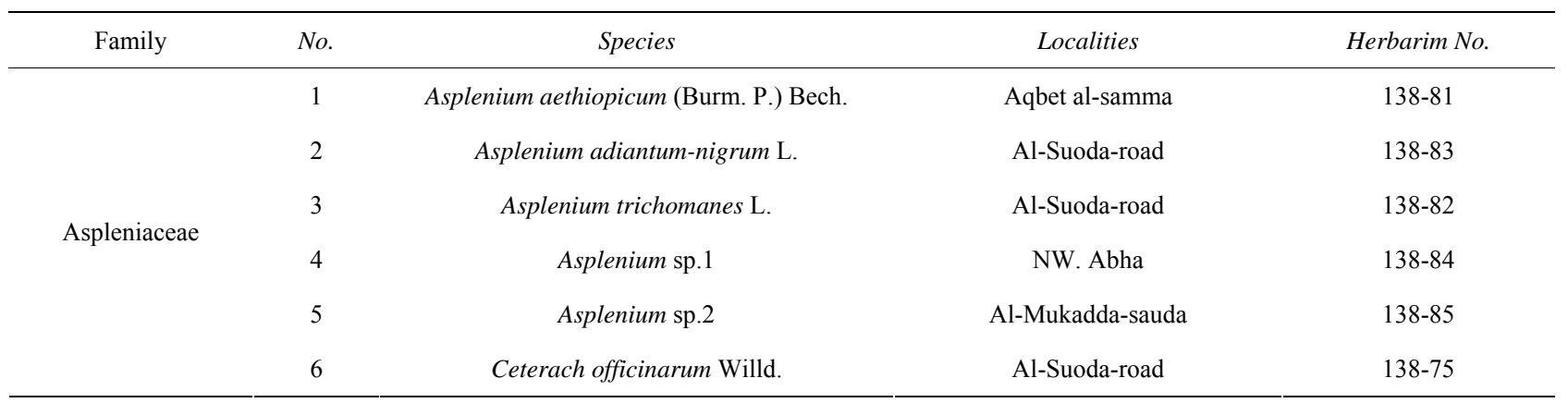

Table 2. Palynological features of the studied species.

\begin{tabular}{|c|c|c|c|c|c|c|c|}
\hline No. & Species & P. $\mu \mathrm{m}$ & E. $\mu \mathrm{m}$ & P/E ratio & $\begin{array}{l}\text { Exospore (perine) } \\
\text { thicking } \mu \mathrm{m}\end{array}$ & Sculptures of exospore & Shape types \\
\hline 1 & Asplenium aethiopicum & $32.5-35$ & $35-37.5-40$ & 0.9 & $4.0-5.0$ & cristates & monolete \\
\hline 2 & Asplenium trichomanes & $20-22.5$ & $20-22.5$ & 1.0 & $2.5-2.3$ & cristates scabrates & monolete \\
\hline 3 & Asplenium adiantum-nigrum & $20-25-30$ & $25-27.5-32.5$ & 0.86 & $2.3-2.5$ & $\begin{array}{l}\text { Cristates } \\
\text { granulate }\end{array}$ & monolete \\
\hline 4 & Asplenium sp.1 & $20-22.5-32.5$ & $20-30-37.5$ & 0.85 & $2.5-3.8$ & regulate scabrates & Trilete \\
\hline 5 & Asplenium sp.2 & $37.5-42.5-49$ & $35-42.5-50$ & 1.01 & $2.4-2.5$ & $\begin{array}{l}\text { papillate to } \\
\text { tuberculate }\end{array}$ & monolete \\
\hline 6 & Ceterach officinarum & $12-14$ & $11-12-13-14$ & 1.04 & $1-1.5$ & $\begin{array}{l}\text { Cristates } \\
\text { granulate }\end{array}$ & Trilete \\
\hline
\end{tabular}


Table 3. Comparison between the studied specimens (2) and the specimens studied by AL Shehri, 2002 (1). (+) Species studied before but no data, $(-)$ species not studied before.

\begin{tabular}{|c|c|c|c|c|c|c|c|c|c|c|}
\hline \multirow{2}{*}{$\begin{array}{c}\text { Species } \\
\text { characters }\end{array}$} & \multicolumn{2}{|c|}{ Asplenium aethiopicum } & \multicolumn{2}{|c|}{ Asplenium trichomanes } & \multicolumn{2}{|c|}{$\begin{array}{c}\text { Asplenium } \\
\text { adiantum-nigrum }\end{array}$} & \multicolumn{2}{|c|}{ Ceterach officinarum } & \multirow{2}{*}{$\begin{array}{l}\text { Asplenium } \\
\text { sp. } 1\end{array}$} & \multirow{2}{*}{$\begin{array}{l}\text { Asplenium } \\
\text { sp. } 2\end{array}$} \\
\hline & 1 & 2 & 1 & 2 & 1 & 2 & 1 & 2 & & \\
\hline $\begin{array}{l}\text { Diameter } \\
\text { size } \mu \mathrm{m}\end{array}$ & $70 \times 50$ & $33 \times 38$ & $50 \times 53$ & $21 \times 21$ & + & $25 \times 29$ & $80 \times 90$ & $11 \times 14$ & - & - \\
\hline Shape class & prolate & subspheroidal & kidney shape & spheroidal & + & subspheroidal & spherical & spheroidal & - & - \\
\hline Shape type & $\begin{array}{c}\text { monoporates or } \\
\text { monosulcates }\end{array}$ & monolates & monosulcate & monolates & + & monolates & $\begin{array}{l}\text { Monoporates or } \\
\text { monosulcates }\end{array}$ & triletes & - & - \\
\hline $\begin{array}{l}\text { Exospores } \\
\text { sculptures }\end{array}$ & nearly regulates & cristates & $\begin{array}{l}\text { irregular } \\
\text { reticulates }\end{array}$ & $\begin{array}{l}\text { cristates } \\
\text { scabrates }\end{array}$ & + & $\begin{array}{l}\text { Cristates } \\
\text { granulate }\end{array}$ & $\begin{array}{l}\text { Regulates } \\
\text { reticulates }\end{array}$ & $\begin{array}{l}\text { Cristates } \\
\text { granulate }\end{array}$ & - & - \\
\hline
\end{tabular}

2) Asplenium adiantum-nigrum L.

Asplenium adiantum-nigrum L. (= A. lucidum Burm.f.)

Asplenium adiantum-nigrum ssp. adiantum-nigrum (Tausch) Koch.

Asplenium adiantum-nigrum ssp. serpentini (Tausch) Koch.

Black spleenwort (A. adiantum-nigrum), Spores are monolete, oblate-spheroidal, sometimes large and compressed, with an irregularly granules to cristate perine and winged folds with a few ridges. Spores are brown and varied in size from 20 - $30 \mu \mathrm{m}$ in polar diameter and $25-32.5 \mu \mathrm{m}$ in equatorial diameter (Figures 1(b), $\times 1000$ and see Table 2). The sori and the underside of the frond are covered with brownish scales on the young fronds and $1-2$ $\mathrm{cm}$ in length.

\section{3) Asplenium trichomanes L.}

Asplenium trichomanes ssp. quadrivalens D.E. Meyer. Asplenium trichomanes ssp. trichomanes L.

Asplenium trichomanes subsp. coriaceifolium D.E. Meyer.

Spores are monolete, spheroidal, sometimes large and compressed, with an scabrates to cristate perine and wavy folds with a few ridges. Spores are brown or yellowish colour. The spores averaged and varied in size from $20-22.5 \mu \mathrm{m}$ in polar diameter and $20-22.5 \mu \mathrm{m}$ in equatorial diameter (Figure 1(c) and see Table 2). The sori are covered with reddish scales on the young fronds and $1-4 \mathrm{~cm}$ in length.

\section{4) Asplenium sp.1}

Spores are trilete, oblate-spheroidal, sometimes large and compressed, with a regularly scabrates exospores and winged folds are absent. Non-perinate, smooth or slightly granulates. Spores are light-brown or yellowish and varied in size from $20-32.5 \mu \mathrm{m}$. in polar diameter and 20 $37.5 \mu \mathrm{m}$, in equatorial diameter (Figure 2(a), $\times 1000$ and see Table 2). The sori and the underside of the frond are covered with yellowish brown scales on the young fronds and $1-3 \mathrm{~cm}$ in length.

5) Asplenium sp. 2

Spores are monolete, sub-spheroidal, sometimes large and compressed, with an irregularly papillate to tuberculate perine and wavy folds. The spores averaged and varied in size from 37.5 - $49 \mu \mathrm{m}$ in polar diameter and 35 $50 \mu \mathrm{m}$ in equatorial diameter (Figure 2(b) $\times 1000$ and see Table 2). The sori and the underside of the frond are covered with brownish scales on the young fronds and 1 $-3 \mathrm{~cm}$ length.

6) Ceterach officinarum Willd.

Asplenium ceterach Willd.

Spores are trilete, sub-spheroidal, sometimes large and compressed, with an irregularly papillate to tuberculate perine and winged folds. The spores averaged and varied in size from $12-14 \mu \mathrm{m}$ in polar diameter and $11-14 \mu \mathrm{m}$ in equatorial diameter (Figure 2(c), $\times 1000$ and see Table 2). The sori and the underside of the frond are covered with silvery scales on the young fronds which become rusted coloured with age and $1-3 \mathrm{~cm}$ in length.

\section{Discussion}

Asplenium species present in southern West Saudi Arabia produce ridged or cristate ridged spores. These observations are agree with those of several studies for the species spores of the New World [16-19] and for species of the Old World [3,6,20-22]. According to the present observations, the spores sculpture in the six taxa analysed is formed by the outer perispore layer and characteristics of the ridges such as their form, margin and fusion could be useful for systematic purposes. Asplenium aethio- picum spores are monolete in shape type, cristate perine sculptures, winged ridges and characteristic by very thick exospores wall 4.0 - $5.0 \mu \mathrm{m}$. According to pervious works there many differences as in Table 3, spores are monoculcates and regulate sculptures [23]. Asplenium adiantum-nigrum spores are monolete in shape type but its characters has no previous records [23]. But according to [24] he studied the Chinese variety (Asplenium adiantum-nigrum var. yuanum (ching) Ching), he found that the sculptures was alar-lophate and echinate used SEM observations. The size diameters was $30.1-46.4 \mu \mathrm{m}$ but in our specimens the sculptures are cristate-granulates 


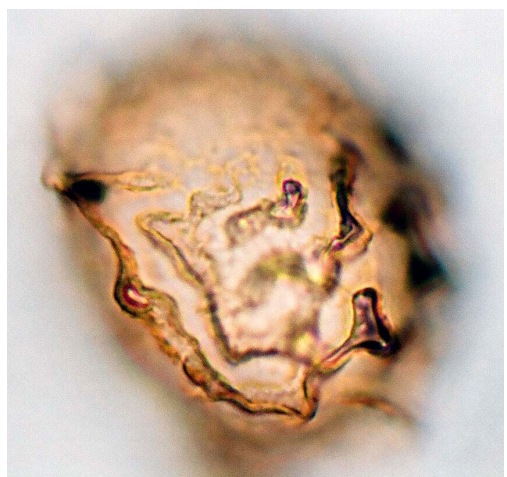

(a1)

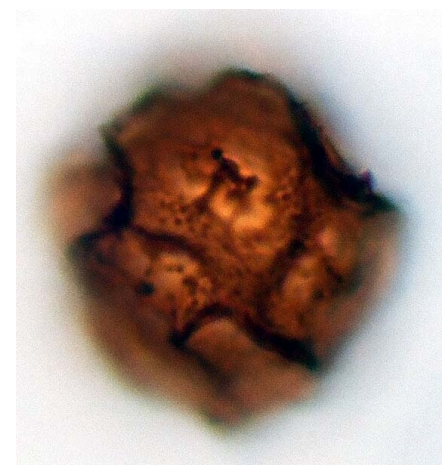

(b1)

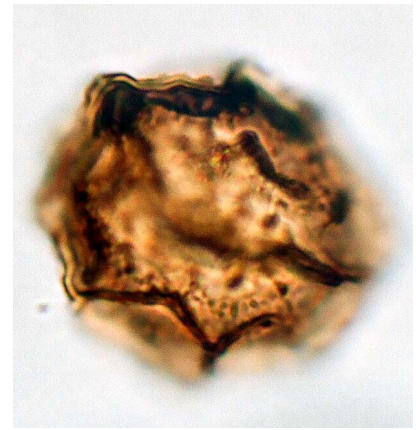

(c1)

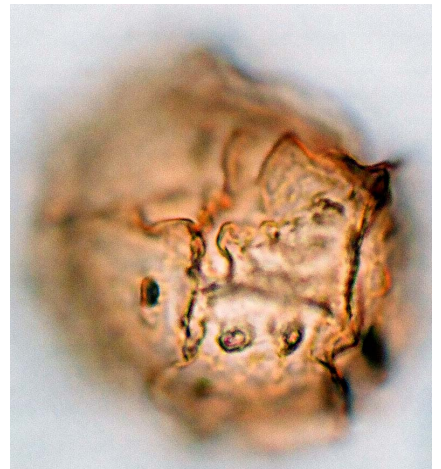

(a2)

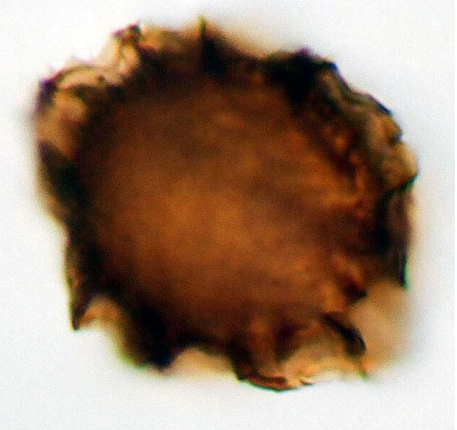

(b2)

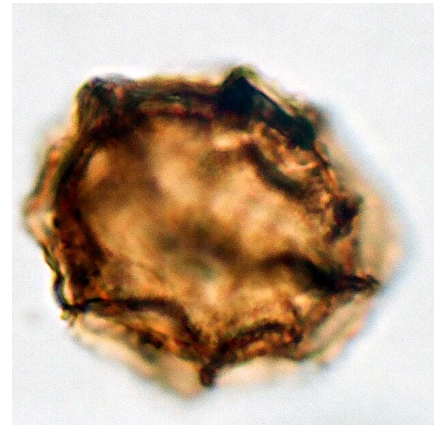

(c2)

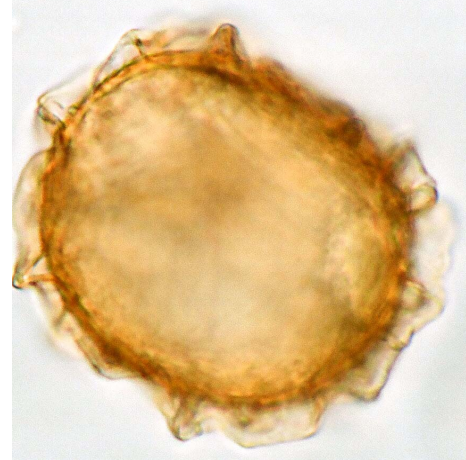

(a3)

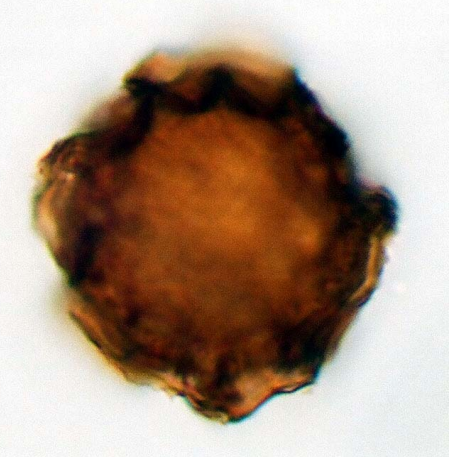

(b3)

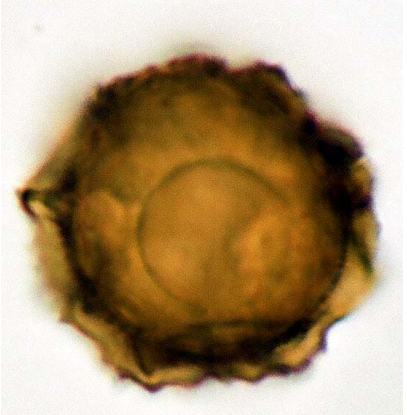

(c3)

Figure 1. (a) Asplenium aethiopicum (Burm. P.) Bech. ((a1)-(a3)), ×1000, (a1) Equatorial view showing cristate sculptures; (a2) Polar view showing monolete mark; (a3) Equatorial view showing folded perine; (b) Asplenium adiantum-nigrum L. ((b1)(b3)), $\times 1000$, (b1) Equatorial view showing cristate sculptures, and monolete mark; (b2) and (b3) Equatorial view showing folded perine; (c) Asplenium trichomanes L. ((c1)-(c3)), ×1000, (c1) Equatorial view showing cristate and verrucate sculptures; (c2) Polar view showing monolete mark; (c3) Equatorial view showing folded perine.

and the size diameter is smaller than the Chinese variety $(20-32 \mu \mathrm{m})$. There are few references about the structure of the exospore in Asplenium. [25] described the exospore in Asplenium adiantum-nigrum L. as homogenous, granular or completely undifferentiated. Asplenium trichomanes spores are monolete cristate-scabrate and very small in size. By [23], the spores were monoculcate and reticulate sculptures, size $21 \times 21 \mu \mathrm{m}$ in diameter. The Chinese species according to [24], the sculptures alar-lophate and size, $24.3-34.3 \mu \mathrm{m}$ were medium. As- plenium sp.2 not described by [23], but in general characters the species belong to genus Asplenium. Ceterach officinarum spores are trilete in shape type and it is the main difference between the genus Asplenium. Because all the species of Asplenium are monolete type [6,22]. I agree with the separation of Ceterach officinarum species from the genus Asplenium and I don't agree with opinion which fixes it under Asplenium officinarum. In [23], the size of Asplenium officinarum is very large $(80-90 \mu \mathrm{m})$ but in present studies it is very small $11-14 \mu \mathrm{m}$ in di- 


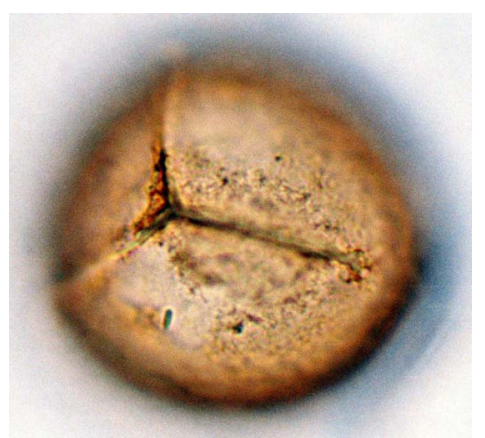

(a1)

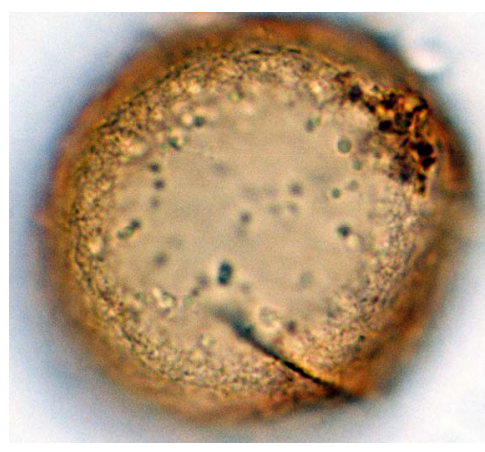

(a2)

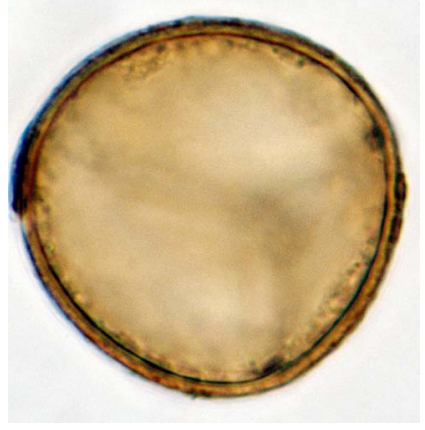

(a3)

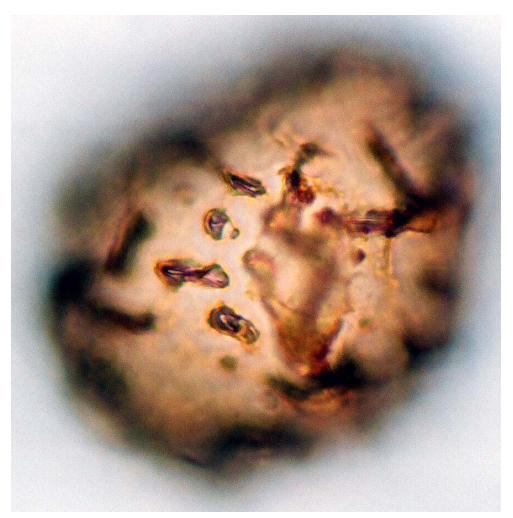

(b1)

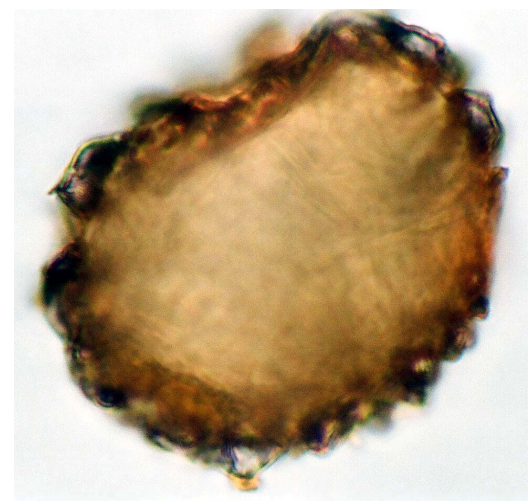

(b2)

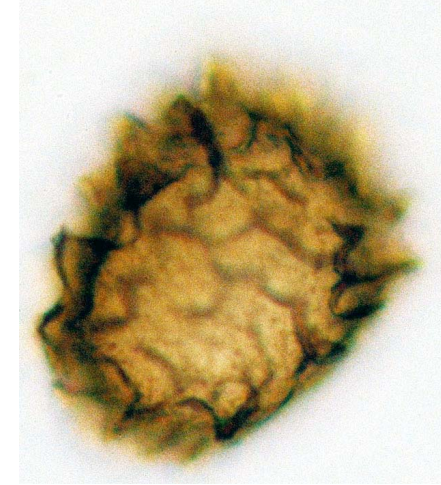

(c1)

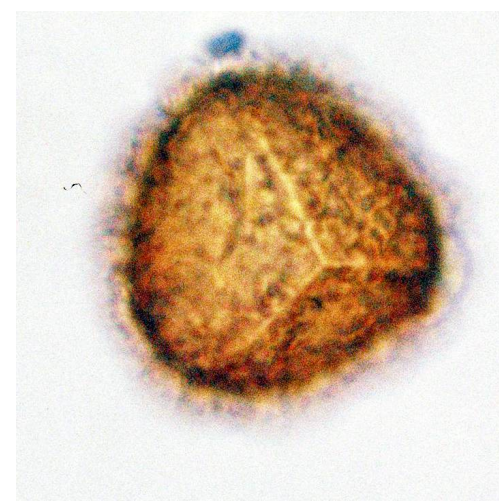

(c2)

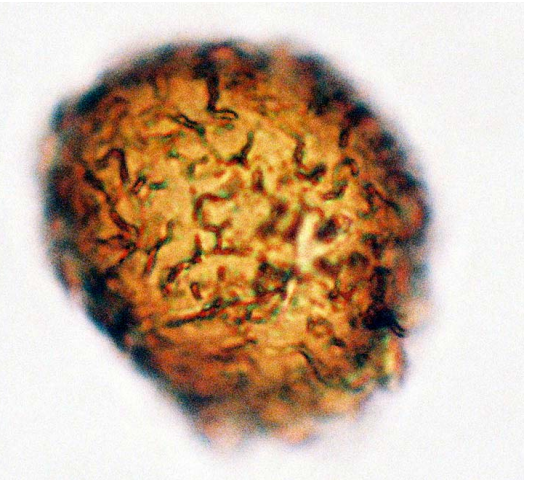

(c3)

Figure 2. (a) Asplenium sp.1 ((a1)-(a3)), $\times 1000$, (a) Polar view showing trilete mark; (b) Equatorial view showing vrrucate sculptures; (c) Polar view showing exospore thickness; (b) Asplenium sp.2 ((b1) and (b2)), ×1000, (b1) Polar view showing papillate to tuberculate sculptures and monlete mark; (b2) Equatorial view showing perispore thickness; (c) Ceterach officinarum Willd. ((c1) and (c2)), ×1000, (c1) and (c2) Equatorial view showing cristate sculpture; (c3) Polar view showing trilete mark and exospore thickness.

ameters. By [24], the sculptures fibrate-alate and the size was medium between Chinese and Al-shehri species. Asplenium sp.1 spores are trilete in shape it could better put under the genus Ceterach. [26], described the exospore in Aspleniaceae as blechnoid type. The perispore ultrastructure in the species examined here are compared with those other genera of Filicophyta in former studies $[1,23]$, considered the perispore structure in Asplenium serra as pillared and pointed out that this particular structure resembled the columellate characters, typical of the Angiosperm pollen exine. The ultrastructure of Asplenium serra was found similar to that of Oleandra articulata (Sw.) Pr. (Oleandraceae) according to the records which given by [6]. With regard to the perispore layer observed here in the present specimens $[26,27]$ was described in some species of Aspleniaceae that layer with similar characters. Studies of spore development are needed in order to understand the sequence of events that 
determine the formation of the perispore layers and strata as well as to understand their possible functions (formation of the gametophyte generation).

\section{Conclusions}

1) Cetraech officinarum is trilete spores for this reasons it's disputed to put under the genus Asplenium (Asplenium officinarum), because Asplenium species are monolete spores as recorded before. 2) Asplenium sp.1 also is trilete in spores type it could be under the genus Ceterach for the same reasons. 3) All features and main ferns spores characters which recorded before by [23] need more revision according to the main and the principles terminology of the Palynologists.

The characteristics shared by all the species are: 1) the general structure and stratification of the exospore; 2) the presence of cristate sculptures on the exospore at the inner part of the perispore.

\section{REFERENCES}

[1] A. Tryon, "Fern Spores: Evolutionary Levels and Ecological Differentiation," Plant Systematics and Evolution, Suppl. 5, 1990, pp. 71-79.

[2] T. Reichstein, "Hybrids in European Aspleniaceae (Pteridophyta)," Botanica Helvetica, Vol. 91, No. 1, 1981, pp. 89-139.

[3] G. J. Gastony, "Electrophoretic Evidence for the Origin of a Fern Species by Unreduced Spores," American Journal of Botany, Vol. 73, No. 11, 1986, pp. 1563-1569. doi:10.2307/2443923

[4] H. Schneider, E. Schuettpelz, K. M. Pryer, R. Cranfill, S. MagallÓn and R. Lupia, "Ferns Diversified in the Shadow of Angiosperms," Nature, Vol. 428, No. 6982, 2004, pp. 553-557. doi:10.1038/nature02361

[5] H. Schneider, "Origin of the Endemic Fern Genus Diellia Coincides with the Renewal of Hawaiian Terrestrial Life in the Miocene," Proceedings of the Biological Science, Vol. 272, No. 1561, 2005, pp. 455-460. doi:10.1098/rspb.2004.2965

[6] R. Tryon and B. Lugardon, "Spores of Pteridophyta," Springer-Verlag, New York, 1991. doi:10.1007/978-1-4613-8991-0

[7] K. U. Kramer and R. Viane, “Aspleniaceae,” In: K. Kubitzki, et al., Eds., The Families and Genera of Vascular Plants, Springer, Berlin, 1990, pp. 52-56.

[8] J. T. Mickel, "The Classification and Phylogenetic Position of the Dennstaedtiaceae," In: A. Jermy, J. Crabbe and B. Thomas, Eds., The Phylogeny and Classification of the Ferns, Academic Press, 1973, pp. 135-144.

[9] A. M. Al-Shehri and G. M. A. Lashin, “An Illustrated Description of Selaginella imbricata and Selaginella yemensis Sporophytes from Saudi Arabia," Research Journal of Botany, Vol. 4, No. 1, 2009, pp. 48-54. doi:10.3923/rib.2009.48.54

[10] G. M. A. Lashin, "Fine Structures of Some Bryoflora Spores from Saudi Arabia," The Egyptian Journal of Ex- perimental Biology, Vol. 7, No. 1, 2011, pp. 1-7.

[11] A .M. Migahid, "Flora of Saudi Arabia," 2nd Edition, University Publications, Riyadh, 1978.

[12] S. Collenette, "An Illustrated Guide to the Flora of Saudi Arabia," Asclepiad Society Publications Ltd., London. 1985.

[13] S. Collenette, "Wild Flora of Saudi Arabia," International Asclepiad Society Publications Ltd., London, 1998.

[14] G. Erdtman, "Pollen and Spore Morphology and Plant Taxonomy: Gymnospermae, Pteridophyta, Bryophyta (Illustrations)," Almqvist \& Wiksell, Stockholm, 1957.

[15] B. Erdtman, "The Acetolysis Method: A Revised Description," Svensk Bot, Tidskr, 1960, pp. 561-564.

[16] G. Erdtman and P. Sorsa, "Pollen and Spore Morphology/ Plant Taxonomy. Pteridophyta (Test and Additional Illustrations)," Almqvist \& Wiksell, Stockholm, 1971.

[17] D. S. Conant, "A revision of the genus Alsophila (Cyatheaceae) in the Americas," Journal of the Arnold Arboretum, Vol. 64, No. 3, 1983, pp. 333-382.

[18] M. L. Lorscheitter, A. R. Ashraf, P. G. Windisch and V. Mosbrugger, "Pteridophyte Spores of Rio Grande do Sul flora, Brazil. Part II," Palaeontographica Abteilung B, Vol. 251, No. 4-6, 1999, pp. 71-235.

[19] M. L. Lorscheitter, A. Ashraf, P. Windisch, V. Mosbrugger, "Pteridophyte spores of Río Grande do Sul, Brazil: Part IV," Palaeontographica Abteilung B, Vol. 263, No. 1-6, 2002, pp. 1-159.

[20] G. J. Gastony and R. Tryon, "Spore morphology in the Cyatheaceae. II. The Genera Lophosoria, Metaxia, Sphaeropteris, Alsophila and Nephelea," American Journal of Botany, Vol. 63, No. 6, 1976, pp. 738-758. doi: $10.2307 / 2442033$

[21] C. Prada, E. Pangua, P. Blanco, P. Cubas and C. Pardo, "Las Aspleniaceae de los Herbarios de Mutis e Isren," Anales Jardín Botnico de Madrid, Vol. 46, No. 2, 1989, pp. 539-552.

[22] R. J. Johns, "Spore Ornamentation and the Species of Simple-Fronded Asplenium (Aspleniaceae), in West Africa," In: M. M. Harley, C. Morton and S. Blackmore, Eds., Pollen and Spores Morphology and Biology, Royal Botanical Gardens, Kew, 2000, pp. 133-146.

[23] A. M. Al-Shehri, "Pteridophytes of Tanumah Mountains Aseer Region South-West Saudi Arabia," Arab Gulf Journal of Scientific Research, Vol. 20, No. 2, 2002, pp. 68-73.

[24] X.-L. Dai, Q.-X. Wang and W.-M. Bao, "Spore Morphology of Pteridophytes from China V.," Aspleniaceae Acta Phytotaxonomica Sinica, Vol. 43, No. 3, 2005, pp. 246-261.

[25] J. M. Pettitt, "Exine Structure in Some Fossil and Recent Spores and Pollen as Revealed by Light and Electron Microscopy," Bulletin British Museum (National History): Geology Series, Vol. 13, No. 4, 1966, pp. 15-257.

[26] B. Lugardon, "La Structure Fine de Léxospore et de Lapérispore des Filicinées Issosporés. II Filicales. Commentaires," Pollen Spores, Vol. 16, No. 2, 1974, pp. 161-226.

[27] B. Lugardon, "Contribution à la Connaissance de la Morphogénèse et de la Structure des Parois Sporales Chez les Filicinées Isosporées," Thése, Universite' Paul Sabatier, Toulouse, 1971. 